\title{
IMPLEMENTASI STRATEGI BELAJAR KOOPERATIF MURDER TERHADAP PEMAHAMAN KONSEP FISIKA PESERTA DIDIK
}

\section{THE IMPLEMENTATION OF MURDER COOPERATIVE LEARNING STRATEGY ON UNDERSTANDING PHYSICAL CONCEPT OF STUDENTS}

\author{
Nurhidayah'1), Thamrin Tayeb ${ }^{2)}$, Nidya Nina Ichiana ${ }^{3)}$, Santih Anggereni' ${ }^{4}$, Andi \\ Kusumayanti5), Andi Ulmi Asnita6) \\ 1,2,3,4,5,6)Fakultas Tarbiyah dan Keguruan Universitas Islam Negeri Alauddin Makassar \\ nurhidayah@gmail.com ${ }^{1)}$, thamrin.tayeb@uin-alauddin.ac.id ${ }^{2}$, nidyanina.ichiana@uin- \\ alauddin.ac.id ${ }^{3}$, santih.anggereni@uin-alauddin.ac.id ${ }^{4}$, andi.kusumayanti@uin-alauddin.ac.id(5), \\ ulmi.asnita@uin-alauddin.ac.id(6)
}

\begin{abstract}
Abstrak
Penelitian ini merupakan penelitian quasi experiment yang bertujuan untuk mengetahui pemahaman konsep fisika peserta didik yang diajar dengan strategi belajar kooperatif MURDER dan peserta didik yang tidak diajar dengan strategi belajar kooperatif MURDER kelas XI IPA SMAN 6 Wajo. Desain penelitian yang digunakan pada penelitian ini yaitu the matching-only posttest-only control group design. Populasi pada penelitian ini yaitu seluruh kelas XI IPA SMAN 6 Wajo yang terdiri dari 4 kelas dengan jumlah keseluruhan 151 peserta didik. Sampel pada penelitian ini dipilih dengan menggunakan teknik matching sehingga diperoleh 2 kelas dengan jumlah keseluruhan peserta didik 61. Hasil penelitian menunjukkan bahwa terdapat perbedaan pemahaman konsep fisika antara peserta didik yang diajar dengan strategi belajar MURDER dan peserta didik yang diajar dengan metode ceramah XI IPA SMAN 6 Wajo. Implikasi dari penelitian ini adalah perlunya memperhatikan media dan sumber belajar yang digunakan peserta didik dalam proses investigasi dalam menerapkan strategi belajar MURDER dan tanpa menerapkan strategi belajar MURDER.
\end{abstract}

Kata Kunci: strategi belajar MURDER, pemahamaan konsep fisika

\begin{abstract}
This research is quasi-experimental research, which aims to find out understanding physical concept of students who are not taught and students who are taught with cooperative MURDER learning strategies class XI IPA SMAN 6 WAJO. The research design used in this research is the matching-only posttest-only control group design. The population in this study is the entire class XI IPA SMAN 6 Wajo consisting of 4 classes with a total of 151 learners. The samples in this study were chosen by using a matching technique to obtain 2 classes with the total number of students 61. The results is there is a different understanding of physics concepts between learners who are taught with learning strategies MURDER and learners who were not taught learning strategies MURDER XI IPA SMAN 6 Wajo. The implications of this research are the need to pay attention to the media and learning resources used by students in the investigation process in applying MURDER learning strategy and without implementing MURDER learning strategy.
\end{abstract}

Keywords: MURDER learning strategies, physics concept understanding

How to Cite: Nurhidayah, Tayeb, T., Ichiana, N.N., Anggereni, S., Kusumayanti, A., \& Asnita, A.U. (2020). Implementasi strategi belajar kooperatif MURDER terhadap pemahaman konsep fisika peserta didik. Al asma: Journal of Islamic Education, 2(1), 74-80. 


\section{PENDAHULUAN}

Pendidikan pada dasarnya merupakan usaha sadar yang dilakukan oleh generasi penerus sebagai peserta didik guna mengembangkan potensi yang dimiliki dengan bantuan seorang pendidik. Dalam Undang-Undang Republik Indonesia nomor 20 tahun 2003 tentang sistem pendidikan nasional BAB I Pasal 1 disebutkan bahwa "Pendidikan adalah usaha sadar dan terencana untuk mewujudkan suasana belajar dan proses pembelajaran agar peserta didik secara aktif mengembangkan potensi dirinya untuk memiliki kekuatan spiritual keagamaan, pengendalian diri, kepribadian, kecerdasan, akhlaq mulia serta ketrampilan yang diperlukan dirinya, masyarakat, bangsa dan Negara".

Pentingnya pendidikan tidak lepas dari pedoman kita sebagai umat muslim yaitu Al-Quran dan Hadits. Orang yang beriman tanpa didasari ilmu tidak akan tahu apa-apa, sedangkan orang yang berilmu tanpa iman maka akan tersesat. Untuk itu sebagai umat muslim kita dianjurkan untuk menambah ilmu pengetahuan sebagai salah satu langkah untuk menguatkan iman kepada Allah Swt. Salah satu cabang dari Ilmu Pengetahuan Alam (IPA) adalah ilmu fisika yang merupakan ilmu yang mempelajari fenomena alam. Ilmu fisika merupakan dasar dari sains adalah ilmu yang diperoleh berdasarkan pengamatan dan eksperimen, serta menghubungkan kenyataan-kenyataan berdasarkan metode ilmiah sehingga keberadaannya sangat penting bagi perkembangan ilmu pengetahuan dan teknologi.

Pemahaman konsep merupakan kompetensi yang ditunjukkan peserta didik dalam memahami konsep dan dalam melakukan prosedur (algoritma) secara luwes, akurat, efisien dan tepat (Dewiatmini, 2010). Kemampuan seseorang untuk mengingat dan memahami informasi penting bergantung pada apa yang mereka telah ketahui dan bagaimana pengetahuan tersebut diatur (Muhibbin, 2004). Pemahaman memerlukan kemampuan menangkap makna atau arti dari suatu konsep (Tohirin, 2006). Pemahaman itu adalah bersifat dinamis, dengan ini diharapkan akan bersifat kreatif (Sardiman, 1996). pemahaman adalah suatu proses mental terjadinya adaptasi dan transformasi ilmu pengetahuan (Susanto, 2013). Pemahaman tampak pada alih bahan suatu bentuk ke bentuk lainnya, penafsiran dan memperkirakan (Hamalik, 2009).

Banyak yang berasumsi bahwa fisika itu merupakan pelajaran yang sulit untuk dimengerti karena selain dipenuhi dengan rumus-rumus juga didasari dengan berbagai konsep yang bagi mereka sulit untuk dipahami. Sehingga dalam proses belajar mengajar timbul suasana yang membosankan. Kandungan dalam materi fisika memuat berbagai rumus dan proses-proses diluar jangkaun manusia dengan kata lain mengandung peristiwa abstrak. Hampir di setiap kompetensi dasar materi fisika memuat rumus. Akan tetapi rumus yang dimuat berasal dari pernyataan biasa sedangkan sifat abstrak yang berasal dari konsep fisika terlihat dari konsep dalam materi itu sendiri.

Berdasarkan observasi di SMAN 6 Wajo, masih banyak ditemui kesulitan peserta didik dalam memahami kosep-konsep fisika. Akibatnya, peserta didik kesulitan dalam memahami konsep-konsep selanjutnya. Terbatasnya alat dan media pembelajaran merupakan hal yang lumrah dalam dunia pendidikan. Pemerintah setempat tidak terlalu memerhatikan hal demikian. Hal ini dirasakan di sekolah di pinggiran kota dan pedesaan seperti di SMAN 6 Wajo. Untuk mengkongkritkan materi yang bersifat abstrak maka fisika membutuhkan suatu media dan alat praktikum sehingga peserta didik mampu memahami dengan tepat konsep yang ada dalam setiap materi fisika. Adapun hal yang membuktikan 
bahwa anak yang mengalami kesulitan dalam belajar fisika, karena mereka bukan memahami konsepnya, melainkan menghafalnya. Ini terlihat dari hasil belajar peserta didik yang kurang dari nilai KKM (Kriteria Ketuntasan Minimum) yang ada di sekolah tersebu. Selain itu tingginya standar KKM yang ada di sekolah khususnya fisika yakni 80 membuat peserta didik sulit untuk mencapainya. Salah satu materi yang sulit untuk dipahami oleh peserta didik di SMAN 6 Wajo adalah materi teori kinetik gas. Hal tersebut dikarenakan materi yang termuat di dalamnya adalah abstrak sehingga membuat peserta didik menghayal mengenai materi tersebut. Melalui wawancara telepon dengan salah satu guru mata pelajaran fisika di sekolah tersebut yang menyatakan bahwa nilai dari peserta didik pada tahun lalu untuk materi momentum dan implus adalah rata-ratanya 76 sehingga guru memberikan remedial kepada peserta didik untuk mencapai standar KKM yang ada.

Salah satu penyebab kurangnya minat belajar fisika peserta didik adalah kurang kondusifnya suatu model atau strategi pembelajaran yang diterapkan oleh seorang guru di dalam kelas. Sedangkan untuk menarik perhatian dan meningkatkan minat belajar peserta didik haruslah dibarengi dengan guru yang bersahabat. Dalam memahami materi fisika memang dibutuhkan suatu keseriusan akan tetapi harus dibarengi dengan sikap santai tapi pasti. Guru harus memiliki cara tersendiri agar peserta didik tertarik dan menyukai pelajaran yang akan disampaikannya. Ketika peserta didik sudah mulai tertarik dengan sikap yang dimiliki oleh guru maka dengan sendirinya menimbulkan ketertarikan terhadap mata pelajaran itu sendiri.

Strategi pembelajaran adalah suatu kegiatan pembelajaran yang harus dikerjakan guru dan peserta didik agar tujuan pembelajaran dapat tercapai secara efektif dan efisien. Strategi pembelajaran itu adalah suatu perangkat materi dan prosedur pembelajaran yang digunakan secara bersama-sama untuk menimbulkan hasil belajar pada peserta didik atau peserta didik (Rusman, 2013). Sistem belajar yang efektif dan efisien dapat dikembangkan menggunakan strategi belajar "MURDER" merupakan singkatan dari Mood (suasana hati), Understand (pemahaman), Recall (pengulangan), Digest (penelaahan), Expand (pengembangan), Review (pelajari kembali) yang diadaptasi dari buku karya Bob Nelson "The Complete Problem Solver". Dengan adanya strategi tersebut diharapkan tercapainya tujuan pembelajaran dalam ranah kognitif. Dalam ranah kognitif memuat kemampuan dalam penguasaan pengetahuan dan pemahaman. Penguasaan pemahaman diartikan sebagai kemampuan dalam menyerap inti dari materi yang ada. Dalam artian pemahaman tidak hanya berpikir semata melainkan bagaiamana seorang peserta didik mengerti secara terperinci makna dari suatu mata pelajaran. Dengan adanya pemahaman yang baik maka peserta didik dapat menjelaskan dengan sendiri makna dari materi dan mampu menjelaskan kepada orang lain.

Hasil penelitian yang dilakukan oleh Juniantari dkk. (2015) menunjukkan bahwa peserta didik yang diajar dengan model pembelajaran kooperatif dengan tipe MURDER pada proses pembelajaran matematika realistik menghasilkan prestasi yang lebih baik dari pada model pembelajaran dengan tipe TPS maupun model pembelajaran langsung. Hasil penelitian Rici Elnanda (2014) memaparkan bahwa peningkatan pemahaman konsep matematika peserta didik yang diajar dengan menggunakan kooperatif MURDER lebih tinggi dibandingkan dengan peserta didik yang tidak diajar dengan strategi belajar MURDER. Dari uraian tersebut, maka peneliti menerapkan strategi MURDER dalam mata 
pelajaran fisika untuk menguji kemampuan pemahaman konsep fisika peserta didik Kelas XI IPA SMAN 6 Wajo Kabupaten Wajo.

\section{METODE PENELITIAN}

Jenis penelitian yang digunakan adalah quasi eksperiment (eksperimen semu). Desain penelitian yang digunakan yaitu the matching-only post-test-only kontrol group design. Pada desain ini menggunakan dua kelas yaitu kelas kontrol dan kelas eksperimen. Kelas kontrol diberikan pembelajaran secara konvensional dan kelas eksperimen digunakan strategi pembelajaran MURDER. Sementara responden untuk setiap kelas eksperimen maupun kelas kontrol ditentukan dengan cara penyetaraan atau pemasangan sampel (matching). Setelah itu sampel diberi perlakuan (treatment) dan ditahap akhir, sampel diberikan post-test.

Populasi dalam penelitian ini adalah seluruh peserta didik kelas XI IPA SMAN 6 Wajo yang berjumlah 151 orang. Menurut (Darmadi, 2013), sampel adalah sebagian dari populasi yang dijadikan objek/subjek penelitian. Sampel dalam penelitian ini sebanyak 2 kelas dimana kelas XI IPA 1 sebagai kelas eksperimen dan kelas XI IPA 3 sebagai kelas kontrol. Peserta didik di kelas XI IPA 1 sebanyak 20 orang dan peserta didik di kelas XI IPA 3 sebanyak 20 orang jadi jumlah keseluruhan sebanyak 40 orang. Teknik pengumpulan data yang dilakukan pada penelitian ini menggunakan tes pemahaman konsep dan lembar observasi. Teknik analisis data menggunakan analisis statistik deskriptif dan analisis statistik inferensial.

\section{HASIL DAN PEMBAHASAN}

Berikut adalah hasil analisis deskriptif kemampuan pemahaman konsep fisika peserta didik pada kelas eksperimen yaitu perlakuan dengan model pembelajaran MURDER kelas XI IPA 1 SMAN 6 Wajo.

Tabel 1. Data Posttest Kelas Eksperimen

\begin{tabular}{cc}
\hline Parameter & Nilai \\
\hline Nilai Maksimun & 90 \\
Nilai Minimum & 60 \\
Rata-rata & 74 \\
Standar Deviasi & 9,54 \\
Varians & 91,05 \\
Koefisien Variasi & $12,89 \%$ \\
\hline
\end{tabular}

Berdasarkan Tabel 1, nilai maksimum yang diperoleh pada kelas eksperimen dengan menggunakan analisis deskriptif sebesar 90 dan nilai minimum sebesar 60 dengan rata-rata perolehan nilai sebesar 74 pada kategori 0-100.

Berdasarkan data yang diperoleh dari hasil analisi deskriptif, maka pemahaman konsep fisika peserrta didik SMAN 6 Wajo pada kelas eksperimen setelah perlakuan dengan model pembelajaran MURDER dikategorikan dalam kategori pemahaman konsep seperti pada Gambar 1. 


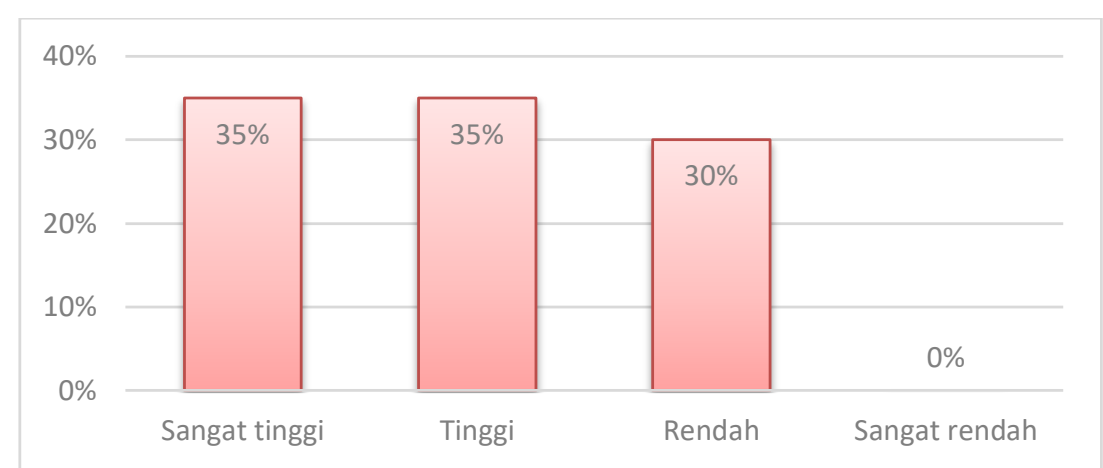

Gambar 1. Kategorisasi Tingkat Pemahaman Konsep Kelas Eksperimen

Berdasarkan Gambar 1, kelas eksperimen setelah diberikan perlakuan berada pada kategori tinggi sebanyak 35\%. Namun, masih terdapat sebanyak 30\% peserta didik dengan kemampuan pemahaman konsep fisika pada kategori rendah. Berdasarkan wawancara melalui via whatsapp, beberapa alasan yang mereka lontarkan diantaranya kurang teliti dalam membaca soal. Adapula yang mengatakan kurang fokus dengan alasan kurang sehat dalam mengerjakan soal. Bahkan diantara mereka ada yang mengatakan bahwa soal yang dibagikan terlalu panjang. Selain itu, ada salah satu diantara mereka yang mengaku sulit dalam belajar tapi dikarenakan peneliti tetap berusaha agar peserta didik tersebut dapat tertarik dengan materi pelajaran melalui strategi belajar yang diterapkan yakni MURDER sehingga peserta didik tersebut mengaku senang dan bisa menjawab soal berdasarkan kemampuannya sendiri.

Berikut ini hasil analisis deskriptif nilai pemahaman konsep fisika peserta didik pada kelas kontrol tanpa menerapkan model pembelajaran MURDER kelas XI IPA 3 SMAN 6 Wajo.

Tabel 2. Data Posttest Kelas Kontrol

\begin{tabular}{cc}
\hline Parameter & Nilai \\
\hline Nilai Maksimum & 85 \\
Nilai Minimum & 40 \\
Rata-rata & 62,5 \\
Standar Deviasi & 11,64 \\
Varians & 135,53 \\
Koefisien Variasi & $18,62 \%$ \\
\hline
\end{tabular}

Berdasarkan Tabel 2, nilai maksimum yang diperoleh pada kelas kontrol dengan menggunakan analisis deskriptif sebesar 85 dan nilai minimum adalah 40 dengan ratarata perolehan nilai sebesar 62,5 pada kategori 0-100.

Berdasarkan data yang diperoleh dari hasil analisis deskriptif, maka pemahaman konsep fisika peserta didik SMAN 6 Wajo pada kelas kontrol tanpa menerapkan model pembelajaran MURDER dikategorikan dalam kategori pemahaman konsep seperti pada Gambar 2. 


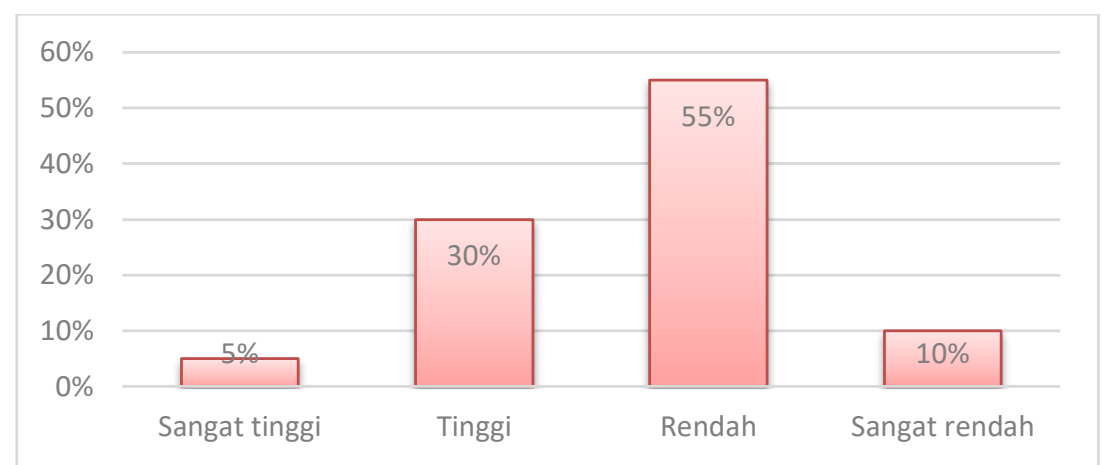

Gambar 2. Kategorisasi Tingkat Pemahaman Konsep Kelas Kontrol

Berdasarkan Gambar 2, kemampuan pemahaman konsep fisika peserta didik kelas control tanpa menerapkan model pembelajaran MURDER pada umumnya berada pada ketagori rendah sebanyak 55\%. Hanya 5\% peserta didik berada pada kategori sangat tinggi, dan masih ada $10 \%$ peserta didik berada pada kateri sangat rendah.

Selanjutnya, untuk mengetahui ada tidaknya perbedaan pada kelas eksperimen dengan menerapkan model pembelajaran MURDER dan kelas kontrol tanpa menerapkan model pembelajaran MURDER, maka dilakukan uji t sampel bebas. Sebagaimana ditampilkan pada Tabel 3.

Tabel 3. Independent Sample t-Test

\begin{tabular}{llcccc}
\hline & \multicolumn{2}{l}{ Levene Tests } & \multicolumn{2}{c}{ t-test for Equality } & \\
\cline { 2 - 5 } & $\boldsymbol{F}$ & Significance & \multicolumn{1}{c}{$\boldsymbol{t}$} & $\boldsymbol{d} \boldsymbol{f}$ & \multirow{2}{*}{ Sig(2-tailed) } \\
\hline Equal Variances &, 270 &, 606 & 3,417 & 38 &, 002 \\
NonEqual Variances & & & 3,417 & 36,590 &, 002 \\
\hline
\end{tabular}

Berdasarkan Tabel 3, nilai signifikan pada uji hipotesis dengan menggunakan program SPSS untuk uji t yaitu 0,002 lebih kecil dari 0,05. Artinya, terdapat perbedaan yang signifikan antara pemahaman konsep fisika peserta didik yang diajar dengan strategi belajar kooperatif MURDER dan peserta didik yang tidak diajar dengan strategi belajar kooperatif MURDER pada kelas XI IPA SMAN 6 Wajo. MURDER merupakan salah satu strategi yang bertujuan mengubah pola diskusi yang ada di dalam kelas. Prosedur yang diterapkan mampu memberikan peserta didik lebih banyak waktu untuk berpikir, menelaah, menjawab, membantu dan bekerjasama serta berinteraksi satu sama lain. Pemahaman konsep yang dimaksud dimana peserta didik tidak hanya mengetahui konsep yang ada dalam mata pelajaran fisika melainkan benar-benar mampu memahami konsep yang ada dengan baik. Kemampuan dalam menyelesaikan masalah yang diberikan mampu diselesaikan melalui proses diskusi.

Kelebihan strategi belajar MURDER yakni peserta didik lebih aktif dalam proses pembelajaran dan mendapat wawasan melalui bertukar pendapat dalam diskusi. Belajar memecahkan masalah yang diberikan secara berkelompok dan terjadi interaksi antar peserta didik yang satu dengan yang lainnya. Selain itu melatih peserta didik dalam mencari dan merangkum informasi serta mendorong peserta didik yang lebih berani dalam menyampaikan pendapatnya. Kooperatif MURDER memberi peluang peserta didik membangun komunitas kerja sama, meningkatkan motivasi motivasi belajar, mengurangi individualisasi dan persaingan, meningkatkan partisipasi peserta didik dalam 
pembelajaran dan dapat meningkatkan pemahaman dan hasil belajar peserta didik. Hal ini akan memberi dampak positif terhadap penguasaan materi yang dipelajari oleh peserta didik itu sendiri. Disisi lain kelemahan strategi belajar MURDER yakni dari sumber belajar yang disediakan sehingga membutuhkan waktu yang cukup lama dalam megumpulkan dan merangkum materi serta terkadang antara peserta didik yang satu dengan lainnya terjadi miskonsepsi. Hasil penelitian ini sejalan dengan penelitian yang dilakukan oleh Rici Elnanda (2014) bahwa kemampuan pemahaman konsep matematik peserta didik yang diajar dengan model pembelajaran collaborative MURDER lebih tinggi daripada peserta didik yang diajar dengan pembelajaran konvensional.

\section{SIMPULAN}

Kemampuan pemahaman konsep fisika peserta didik kelas XI IPA 1 SMAN 6 Wajo yang diajar dengan strategi pembelajaran kooperatif MURDER berada pada kategori tinggi dengan rata-rata perolehan nilai sebesar 74 pada kategori 0-100, kemampuan pemahaman konsep fisika peserta didik kelas XI IPA 3 SMAN 6 Wajo yang diajar tanpa menggunakan strategi pembelajaran kooperatif MURDER berada pada kategori rendah dengan rata-rata perolehan nilai sebesar 62,5 pada kategori $0-100$, terdapat perbedaan pemahaman konsep fisika peserta didik kelas XI SMAN 6Wajo yang diajar dengan strategi pembelajaran kooperatif MURDER dan peserta didik yang tidak diajar dengan strategi pembelajaran kooperatif MURDER. Implikasi dari penelitian ini adalah perlunya memperhatikan media dan sumber belajar yang digunakan peserta didik dalam proses investigasi dalam menerapkan strategi belajar MURDER dan tanpa menerapkan strategi belajar MURDER.

\section{DAFTAR PUSTAKA}

Darmadi, H. (2013). Metode Penelitian dan Sosial. Alfabeta.

Dewiatmini, P. (2010). Upaya Meningkatkan Pemahaman Konsep Matematika pada Pokok Bahasan Himpunan Siswa Kelas VII A SMP Negeri 14 Yogyakarta dengan Penerapan Model Pembelajaran Kooperatif Tipe Student Teams Achievement Divisions (STAD). In Skripsi. Universitas Negeri Yogyakarta.

Elnanda, R. (2014). Pengaruh Model Pembelajaran Collaborative MURDER terhadap Kemampuan Pemahaman Konsep Matematik Siswa (Penelitian Quasi Eksperimen Terhadap Siswa Kelas VII SMPI Al Azhar 25 Pamulang).

Hamalik, O. (2009). Strategi Belajar Mengajar Berdasarkan CBSA. Sinar Baru Algensido.

Juniantari, M., Sariyasa, \& Sadra, I. W. (2015). Pengembangan Perangkat Pembelajaran Matematika Realistik Bagi Siswa SMP Kelas VII dengan Setting Model Kooperatif MURDER. Seminar Nasional FMIPA UNDIKSHA V, 178-183.

Muhibbin, S. (2004). Psikologi Pendidikan dengan Pendekatan Baru. Remaja Rosdakarya.

Rusman. (2013). Model-Model Pembelajaran Edisi kedua. Raja Grafindo Persada.

Sardiman. (1996). Interaksi dan Motivasi Belajar Mengajar. Raja Grafindo Persada.

Susanto, A. (2013). Teori Belajar dan Pembelajaran di Sekolah Dasar. Kencana Prenada Media Grup.

Tohirin. (2006). Psikologi Pembelajaran Pendidikan Agama Islam. Raja Grafindo Persada. 